\title{
A voyage of discovery
}

Summarize yourself in the form of a title of a paper in Nature.

Thought experiments linking ocean ecology and biogeochemistry with species evolution.

What was your first experiment as a child (on pets/siblings/dead flies, and so on)?

When I was small, my elder sister suggested that I tease our sleeping dalmatian by poking him with a stick. He growled and we giggled. Suddenly he lost his temper, jumped up and bit me in the shoulder. The wound healed but the lessons remained.

Who has been the most important mentor in your career?

Johannes Krey, chair of the department of planktology at the Institute for Marine Research in Kiel. He took me under his wing on my arrival in Germany in 1964 at the age of 18 . Krey was an exceptionally kind, sensitive man, of humorous inclination and excited by his science.

\section{What makes a good scientific mentor?}

This depends on the student. Some need to be guided to the details, others to the big picture. The ocean is still full of surprises so the good mentor maintains an open mind and teaches why honesty is the best policythat is, a dispassionate interpretation of the full data set with particular attention to the outliers, which could be the exceptions that prove the rule.

What single scientific paper or talk changed your career path?

An article in the Reader's Digest entitled "Bread from the sea", which I read in my teens. I was always obsessed with biology so when I was offered a scholarship to study in Germany I picked marine biology and was sent to Kiel. There were famines in India at the time and I wanted to do something useful.

What book has been most influential in your scientific career?

Salim Ali's Book of Indian Birds, which captured my attention while I was still a toddler (according to my mother).

What gives you the most job satisfaction now? What are your major frustrations?

Discussing perplexing questions in marine science with enthusiastic, knowledgeable representatives from different disciplines; interpreting data on interdisciplinary research cruises with 50 scientists cramped in a small room on board $R V$ Polarstern while weathering a storm in the Southern Ocean; creating structure and process in the watery vastness around us from strings of numbers spewed from in situ sensors. What frustrates me most in science is territoriality. To counter the objection that interdisciplinary discussion is mere hand-waving, I coined the term 'heterodisciplinary fertilization'. Territorial males hate to be called homodisciplinary.

\section{What literary character would you employ as apostdoc?}

Puck. His magical powers would ensure success, he would be fun to work with, and I could quote Shakespeare in his reference letter.

What book currently resides on your bedside table?

Mind and Muscle by Elizabeth Langford.

Assuming the dead can be raised and/or time travel exists, who from the world outsidescience would you most like to have dinner with?

Jim Corbett, who had much the same childhood as I did, in the Nainital district of Kumaon in the western Himalayan foothills, albeit 70 years earlier. He loved roaming the jungles, understood animals in their natural surroundings and matured into a passionate conservationist. He was a sincere, compassionate man who, at great personal risk and hardship, applied his knowledge (he called it 'jungle lore', I would call it nonverbal ecology) to track and shoot many cunning man-eating tigers and leopards that terrorized villages in remote areas. His stories (Man-Eaters of Kumaon, The Temple Tiger and so on) are grippingly authentic and beautiful to read. I wish I could have met this legendary, self-effacing hero.

You are on a plane behind two students obviously going to the same conference, who start to talk about your work. What do you do?

I would introduce myself and beg them to discuss any problems they might have encountered or perceived with my work.

\section{What do you do to relax?}

I relax in our garden and narrow strip of forest bordering the Autobahn. I stroll around, contemplate the landscape between bouts of hard work, keeping my back supple by squatting as much as possible. I also enjoy exploring the evolving mindset of our ancestors by active introspection: putting myself in their position, as down-to-earth as possible. Which is also why I like to squat and work.

What's the best piece of advice you've ever received?

When my father succumbed to my begging

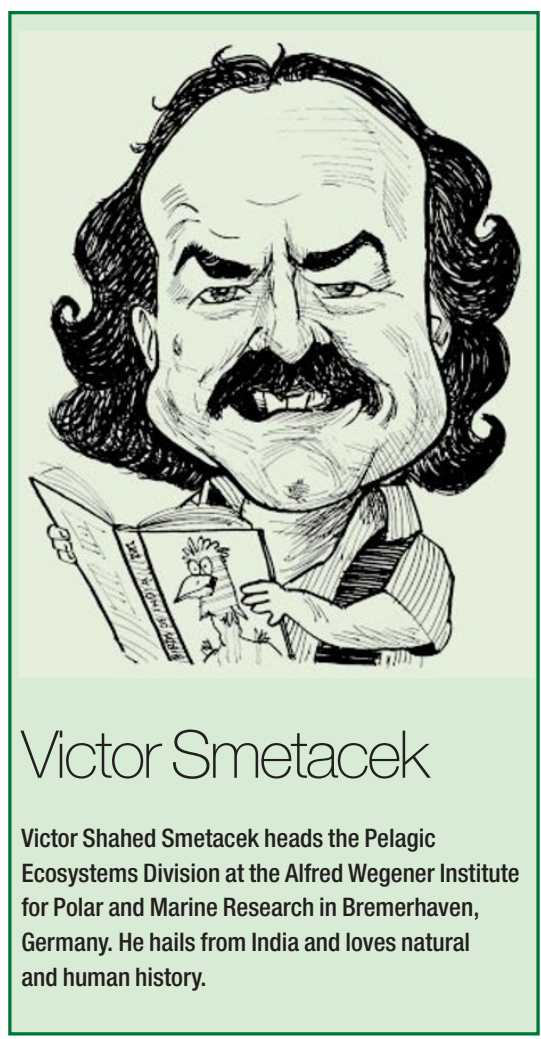

that I be allowed to go hunting with his shotgun at the age of ten, he made me memorize these lines of Victorian vintage: 'Never ever let your gun/ pointed be at anyone./ That it may unloaded be/ matters not the least to me.' He was worried about my safety and that of the many people who collected wood and fodder in the forest. His willingness to trust me made my sense of responsibility surge. I never even came close to an accident in the many subsequent years spent roaming the jungles.

What would you have become, if not a scientist? I would have joined the Indian Forest Department and participated in conserving habitat and wildlife.

What single discovery, invention or innovation would most improve your life?

The discovery of the neural basis of the lust for power over others, and a treatment to correct this atavistic condition.

Name one extravagance you can now get away with because of your eminence.

Spending more time writing, which means going later to the office. I have always been a nightbird and write best under the partial exhaustion that only sets in in the wee hours of the morning.

What music would you have played at your funeral?

The hum of voices of friends meeting one another on the occasion of my passing on. 